\title{
Immersion in water during labor and delivery
}

\author{
Carlo De Angelis ${ }^{1}$ (D), Chiara De Angelis², Fabrizia Santangelo', Gabriele Saccone ${ }^{2}$ (ID, \\ Daniela loffredo', Jessica Anna Cinzia Paino², Attilio Di Spiezio Sardo ${ }^{3}$ \\ ${ }^{I}$ Department of Obstetrics and Gynecology, School of Medicine, University of Roma, Roma, Italy \\ ${ }^{2}$ Department of Neuroscience, Reproductive Sciences and Dentistry, School of Medicine, University of Naples Federico II, Naples, Italy \\ ${ }^{3}$ Department of Public Health, School of Medicine, University of Naples Federico II, Naples, Italy
}

\begin{abstract}
Objective: Immersion in water during labor and delivery has been studied as an alternative form of obstetric care. The aim of this study was to evaluate obstetrics and neonatal outcomes of women intending to use immersion in water for labor and delivery.

Methods: This was a retrospective observational study conducted at a single center in Italy from January 2004 to January 2016. The clinical records of pregnant women intending to use immersion in water for labor and delivery were collected in a dedicated database and included in the study. Only the women who underwent immersion in water starting from the first stage of labor were included in the study. Inclusion criteria were women with uncomplicated singleton gestations and cephalic presentation at or later than 37 weeks of gestation, and with spontaneous onset of labor. The primary outcome of the study was the percentage of women who had both labor and delivery in water.

Results: 389 women met the inclusion criteria and were included in the study. 256 (66\%) were nulliparous, and 133 (34\%) were multiparous. Out of the 389 women intending to use immersion in water for labor and delivery, 278 (71.5\%) had labor and delivery in the water, $31(8.0 \%)$ labor in water and delivery on land, and $80(20.5 \%)$ had the first stage of labor in water, and the second stage and delivery on land. The incidence of perineal lacerations was $61.4 \%$.

Conclusion: The vast majority of the women who set out to labor and delivery in water achieve their aim.
\end{abstract}

Keywords: Cesarean delivery, operative delivery, dystocia, postpartum hemorrhage, NICU.

\section{Introduction}

Immersion in water during labor and delivery has been studied as an alternative form of obstetric care. ${ }^{[1]}$ At the end of 1960, Russian obstetricians Tjarkovsky and

\section{Özet: Suda doğum}

Amaç: Suda doğum yöntemi, obstetrik bakımın alternatif bir biçimi olarak araştırılmaktadır. Çalışmamızda amacımız, suda doğum yapmayı planlayan kadınlarda obstetrik ve neonatal sonuçları değerlendirmekti.

Yöntem: Çalışmamız, Ocak 2004 ile Ocak 2016 tarihleri arasında İtalya'da tek bir merkezde gerçekleştirilen retrospektif gözlemsel bir çalışmaydı. Suda doğum yapmayı planlayan gebelerin klinik kayıtları özel bir veri tabanında toplandı ve çalışmaya dahil edildi. Sadece doğumun ilk aşamasının başlangıcından itibaren doğum için suya giren gebeler çalışmaya dahil edildi. Komplikasyonsuz tekil gebeliği olan ve gebeliğin 37. haftasında veya öncesinde sefalik gelişi olan kadınlar ile spontane doğum başlangıcı olanlar çalışmaya dahil edilme kriterleri arasındaydı. Çalışmanın birincil sonucu, suda doğum yapan kadınların yüzde oranıydı.

Bulgular: Toplam 389 kadın, dahil edilme kriterlerini karşılayarak çalışmaya alındı. Bunların 256’sı (\%66) nullipar ve 133’ü (\%34) multipardı. Suda doğum yöntemini kullanmayı planlayan 389 gebe kadının 278'i (\% 71.5) suda doğum yaparken, 31'i (\% 8.0) doğuma suda başladı ve su dışında doğum yaptı, 80 'i (\%20.5) ise doğumun ilk aşamasında suda iken, ikinci aşamasında ve doğum sırasında su dişındaydı. Perineal laserasyon insidansı \%61.4 bulundu.

Sonuç: Suda doğum yapmaya başlayan kadınların büyük çoğunluğu amacını gerçekleştirdi.

Anahtar sözcükler: Sezaryen doğum, operatif doğum, distosi, postpartum kanama, yenidoğan yoğun bakım ünitesi.

Leboyer, were the first to get the idea of having the newborn in a warm bath immediately after childbirth. $^{[2,3]}$ Cluett et al. in a recent Cochrane review, including 15 trials, concluded that in healthy women at

Correspondence: Gabriele Saccone, MD. Department of Neuroscience, Reproductive Sciences and Dentistry, School of Medicine, University of Naples Federico II, Naples, Italy. e-mail: gabriele.saccone.1990@gmail.com / Received: August 21, 2020; Accepted: October 9, 2020

Please cite this article as: De Angelis Ca, De Angelis Ch, Santangelo F, Saccone G, Ioffredo D, Cinzia Paino JA, Di Spiezio Sardo A. Immersion in water during labor and delivery. Perinatal Journal 2020;28(3):202-205. doi:10.2399/prn.20.0283012 
low risk of complications, water immersion during the first stage of labor has beneficial effects on mode of birth and on perineal trauma and may reduce the use of regional analgesia. ${ }^{[1]}$ The evidence during the second stage of labor is limited, ${ }^{[1]}$ and still subject of debate. ${ }^{[4,5]}$ Given this evidence, the American College of Obstetricians and Gynecologists (ACOG) recommends against the immersion in water during the second stage of labor and during the delivery. ${ }^{[4]}$ The Royal College of Obstetricians and Gynaecologists (RCOG) considered immersion in water as an alternative for labor and delivery, but recommends for informing women that there is insufficient high-quality evidence to either support or discourage giving birth in water. ${ }^{[5]}$

The aim of this study was to evaluate obstetrics and neonatal outcomes of women intending to use immersion in water for labor and delivery.

\section{Methods}

This was a retrospective observational study conducted at a single center in Italy (Fabia Mater, Rome, Italy) from January 2004 to January 2016. The clinical records of pregnant women intending to use immersion in water for labor and delivery were collected in a dedicated database and included in the study. Only women who underwent immersion in water for labor and delivery starting from the first stage of labor were included in the study.

All variables reported were collected on all of the subjects included in this study. Inclusion criteria were women with uncomplicated singleton gestations and cephalic presentation at or later than 37 weeks of gestation, and with spontaneous onset of labor. Women with high-risk pregnancies, preterm delivery, and multiple gestations were excluded. Women with induced labor, women who received epidural analgesia, those with augmentation of labor, were also excluded.

For the purpose of this study we defined latent first stage of labor as a period of time when there are painful contractions and some cervical change, including cervical effacement and dilatation up to $4 \mathrm{~cm}$, established first stage of labor as when there are regular painful contractions and there is progressive cervical dilation from $4 \mathrm{~cm}$ to $10 \mathrm{~cm}$, and second stage of labor as the finding of full dilation of the cervix.
The bath pool was large enough to allow the women to have frequent position changes during labor. Water temperature was maintained at $37^{\circ} \mathrm{C}$, and the mother was immersed up to chest level. The immersion in hot water causes a dilation of the blood vessels that could cause tachycardia and hypotension; this is why the women had to leave the tub every two hours for about thirty minutes. Maternal blood pressure, pulse rate and respiratory rate were checked every 30 minutes.

A cardiotocographic monitoring for 20 minutes to ensure wellbeing of the fetus was performed before the immersion in water. Then, the fetal heart rate was recorded once every 15 minutes, with a water proof probe. Women are encouraged to leave the bath to urinate regularly.

The primary outcome of the study was the percentage of women who had both labor and delivery in water. Secondary outcomes were maternal and neonatal outcomes.

\section{Results}

389 women met the inclusion criteria and were included in the study. 256 (66\%) were nulliparous, and $133(34 \%)$ were multiparous. The mean maternal age was 29 years. Mean gestational age was 39 weeks of gestations, ranging from 37 to 41 weeks. The mean of cervical dilation at the time of immersion in water was $5.8 \mathrm{~cm}$, ranging from 3 to 10 (Table 1).

Out of the 389 women intending to use immersion in water for labor and delivery, $278(71.5 \%)$ had labor and delivery in the water, $31(8.0 \%)$ labor in water and delivery on land, and 80 (20.5\%) had the first stage of

Table 1. Characteristics of the included women.

\begin{tabular}{lc} 
& $\mathbf{n = 3 8 9}$ \\
\hline Maternal age (year) & $29.4 \pm 4.2$ \\
\hline Nulliparous & $256(65.8 \%)$ \\
\hline Multiparous & $133(34.2 \%)$ \\
\hline Gestational age & $39.2 \pm 3.7$ \\
\hline Smoking & $40(10.3 \%)$ \\
\hline BMI & $24.7 \pm 5.8$ \\
\hline $\begin{array}{l}\text { Cervical dilatation at the time of immersion } \\
\text { in water (cm) }\end{array}$ & $5.8 \pm 3.1($ range: $3-10)$ \\
\hline Membranes ruptured & $340(87.4 \%)$ \\
\hline
\end{tabular}

Data are presented as number (percentage) or as mean \pm standard deviation 
Table 2. Primary outcome.

\begin{tabular}{lc} 
& $\mathbf{n = 3 8 9}$ \\
\hline First stage, second stage, and delivery in water & $278(71.5 \%)$ \\
\hline First stage, second stage in water. Delivery on land & $31(8.0 \%)$ \\
\hline First stage in water. Second stage, and delivery on land & $80(20.5 \%)$ \\
\hline
\end{tabular}

labor in water, and the second stage and delivery on land (Table 2).

The incidence of perineal lacerations was $61.4 \%$. There were 3 third-degree lacerations ( $0.8 \%)$. Episiotomy was performed in 40 cases (10.3\%). 11 emergent cesarean delivery occurred: 1 for non-reassuring fetal heart rate, and 10 for prolonged second stage of labor. The mean birth weight was $3346 \mathrm{~g}$, and 13 babies (3.3\%) had birth weight $>4000 \mathrm{~g}$ (Table 3). The incidence of postpartum hemorrhage was $11.6 \%$.

\section{Discussion}

While there are enough randomized controlled trials assessing harms and benefits of water immersion during the first stage of labor, there are lack of second stage data. ${ }^{[4,6]}$ Moreover, data regarding percentage of women who achieve the aim of laboring and delivery in water are also lacking. ${ }^{[4,7,8]}$ In this retrospective study of 389 pregnant women, intending to give birth in water during labor and delivery, we found that a large percentage of this women achieved their aim. Only a small percentage of women had to leave the tub during the first or the second stage of labor to give land birth.

Most women who gave birth in water were at their first pregnancy, with an average age of 29 years. This data indicates that young women at their first birth experience are more likely to approach waterbirth to alleviate pain during labor, notoriously longer in nulliparous. ${ }^{[9]}$

Mean gestational age was 39 weeks of gestation, comparable between the women who achieved a water birth and that who left the tub before delivery.

The second main finding of our study was that waterbirth is not associated with significantly high rates of maternal and neonatal adverse outcomes. However, this study was not powered for such outcomes, and limited by the retrospective study design. The incidence of thirddegree was low in the group of woman who gave birth water; they also had lower incidence of episiotomies
Table 3. Maternal and neonatal outcomes.

\begin{tabular}{|c|c|}
\hline & $n=389$ \\
\hline Birth weight (grams) & $3346 \pm 459$ \\
\hline Low birth weight & $6(1.5 \%)$ \\
\hline Macrosomia & $13(3.3 \%)$ \\
\hline Episiotomy & $40(10.3 \%)$ \\
\hline Intact perineum, excluding episiotomy & $150(38.6 \%)$ \\
\hline Any degree laceration & $239(61.4 \%)$ \\
\hline First-degree laceration & $164(42.2 \%)$ \\
\hline Second-degree laceration & $72(18.5 \%)$ \\
\hline Third-degree laceration & $3(0.8 \%)$ \\
\hline Fourth-degree laceration & 0 \\
\hline Uterine atony & $2(0.5 \%)$ \\
\hline Manual removal of the placenta & $3(0.8 \%)$ \\
\hline Operative vaginal delivery & $8(2.1 \%)$ \\
\hline Cesarean delivery & $11(2.8 \%)$ \\
\hline Apgar score $>7$ at $1 \mathrm{~min}$ & 0 \\
\hline Apgar score $>7$ at $5 \mathrm{~min}$ & 0 \\
\hline Apgar score $>7$ at $10 \mathrm{~min}$ & 0 \\
\hline Admission to NICU & $3(0.8 \%)$ \\
\hline
\end{tabular}

compared with women who had a landbirth. A major limitation was that the study had no control group.

Our results concurred to data reported in a recent Cochrane review, that reported an increase in second degree tears with reduction in episiotomy in women who were in an upright position. ${ }^{[1,10,11]}$ These maternal birth position was typically adopted by pool users and it would seem to influence perineal outcomes. ${ }^{[12]}$

\section{Conclusion}

In conclusion, our study showed that among women who intend to have birth water, the vast majority achieved their aim. Based on these findings, immersion in water may be offered as an alternative strategy for labor and delivery in low risk women with singleton gestations and cephalic presentation at term, who planned to give water birth, wishing to reduce pain and have a different experience during labor and delivery. Further studies, including high-quality and well-designed randomized controlled trials, are necessary.

Conflicts of Interest: No conflicts declared. 


\section{References}

1. Cluett ER, Burns E, Cuthbert A. Immersion in water during labour and birth. Cochrane Database Syst Rev 2018;5(5): CD000111. [PubMed] [CrossRef]

2. Odent M. Birth under water. Lancet 1983; 2:1476-7. [PubMed] [CrossRef]

3. Lim KMX, Tong PSY, Chong YS. A comparative study between the pioneer cohort of waterbirths and conventional vaginal deliveries in an obstetrician-led unit in Singapore. Taiwan J Obstet Gynecol 2016;55:363-7. [PubMed] [CrossRef]

4. American College of Obstetricians and Gynecologists' Committee on Obstetric Practice. Committee opinion no. 679: Immersion in water during labor and delivery. Obstet Gynecol 2016;128:e231-e236. [PubMed] [CrossRef]

5. National Collaborating Centre for Women's and Children's Health. Intrapartum care: care of healthy women and their babies during childbirth. London: RCOG; 2007.

6. Vanderlaan J, Hall PJ, Lewitt M. Neonatal outcomes with water birth: a systematic review and meta-analysis. Midwifery 2018;59:27-38. [PubMed] [CrossRef]

7. Taylor H, Kleine I, Bewley S, Loucaides E, Sutcliffe A. Neonatal outcomes of waterbirth: a systematic review and meta-analysis. Arch Dis Child Fetal Neonatal Ed 2016;101: F357-65. [PubMed] [CrossRef]

8. Nutter E, Meyer S, Shaw-Battista J, Marowitz A. Waterbirth: an integrative analysis of peer-reviewed literature. J Midwifery Womens Health 2014;59:286-319. [PubMed] [CrossRef]

9. Woodward J, Kelly SM. A pilot study for a randomised controlled trial of waterbirth versus land birth. BJOG 2004;111: 537-45. [PubMed] [CrossRef]

10. Menakaya U, Albayati S, Vella E, Fenwick J, Angstetra D. A retrospective comparison of water birth and conventional vaginal birth among women deemed to be low risk in a secondary level hospital in Australia. Women Birth 2013;26:114-8. [PubMed] [CrossRef]

11. American Academy of Pediatrics Committee on Fetus and Newborn; American College of Obstetricians and Gynecologists Committee on Obstetric Practice. Immersion in water during labor and delivery. Pediatrics 2014;133:758-61. [PubMed] [CrossRef]

12. Henderson J, Burns EE, Regalia AL, Casarico G, Boulton MG, Smith LA. Labouring women who used a birthing pool in obstetric units in Italy: prospective observational study. BMC Pregnancy Childbirth 2014;14:17. [PubMed] [CrossRef]

Bu makalenin kullanım izni Creative Commons Attribution-NoCommercial-NoDerivs 3.0 Unported (CC BY-NC-ND3.0) lisansı aracılı̆̆ıyla bedelsiz sunulmaktadır. / This work is licensed under the Creative Commons Attribution-NonCommercial-NoDerivs 3.0 Unported (CC BY-NC-ND3.0) License. To view a copy of this license, visit http://creativecommons.org/licenses/by-nc-nd/3.0/ or send a letter to Creative Commons, PO Box 1866 , Mountain View, CA 94042, USA. 